Pengaruh Mind Mapping di Akhir Model Discovery Learning terhadap Hasil Belajar Peserta Didik

Kelas XI IPA SMAN 3 Makassar (Studi pada Materi Pokok Larutan Penyangga)

\title{
Pengaruh Mind Mapping di Akhir Model Discovery Learning terhadap Hasil Belajar Peserta Didik Kelas XI IPA SMAN 3 Makassar (Studi pada Materi Pokok Larutan Penyangga)
}

\author{
The Effect of Mind Mapping at the End of Discovery Learning Model on \\ Learning Outcomes of Student Grade XI IPA SMAN 3 Makassar \\ (Study on Buffer Solution) \\ ${ }^{1)}$ Mutmainna Umar, ${ }^{2)}$ Alimin, ${ }^{3)}$ Army Auliah \\ 123) Jurusan Kimia Fakultas Matematika dan Ilmu Pengetahuan Alam \\ Universitas Negeri Makassar, Jl. Dg Tata Raya Makassar, Makassar 90224 \\ Email:mutmainna788@gmail.com
}

\begin{abstract}
ABSTRAK
Penelitian ini adalah penelitian eksperimen semu bertujuan untuk mengetahui pengaruh mind mapping di akhir model discovery learning terhadap hasil belajar peserta didik kelas XI IPA SMAN 3 Makassar. Variabel bebas dalam penelitian ini adalah mind mapping di akhir pembelajaran menggunakan model discovery learning. Variabel terikatnya adalah hasil belajar peserta didik pada materi pokok larutan penyangga. Populasi penelitian ini adalah terdiri dari enam kelas XI IPA SMA Negeri 3 Makassar. Sampel penelitian terdiri dari dua kelas yaitu kelas XI IPA sebagai kelompok eksperimen yang terdiri dari 36 peserta didik dan kelas $\mathrm{XI}_{\mathrm{IPA}}{ }_{4}$ sebagai kelompok kontrol yang terdiri dari 36 peserta didik yang ditentukan dengan cara teknik pengambilan sampel yaitu simple random sampling. Data hasil penelitian diperoleh dengan memberikan tes hasil belajar pada materi pokok laju reaksi berupa post-test yang dianalisis menggunakan uji Mann-Whitney. Pengujian hipotesis dengan uji MannWhitney menghasilkan $Z_{\text {hitung }}=5,36$, dan diperoleh $Z_{\text {tabel }}=1,64$ pada taraf signifikan $\alpha=0.05$. Oleh karena itu, $Z_{\text {hitung }}>Z_{\text {tabel, }}$, maka hipotesisi pada penelitian ini diterima yang berarti terdapat pengaruh mind mapping di akhir model discovery learning terhadap hasil belajar peserta didik kelas XI IPA SMA Negeri 3 Makassar pada materi pokok larutan penyangga.

Kata Kunci: Mind mapping, model discovery learning, hasil belajar
\end{abstract}

\begin{abstract}
The research is a quasi-experimental that aimed to know the effect of mind mapping at the end of discovery learning toward student's learning outcome in XI IPA class of SMA Negeri 3 Makassar on Buffer Solution Subject Matter. The independent variable in this experiment is mind mapping at the end of discovery learning. The dependent variable was the students' learning outcome on the subject matter buffer solution. The population was XI IPA with six classes of SMA Negeri 3 Makassar and sample classes consisted of two group, namely XI IPA ${ }_{3}$ class as an experiment group with 36 students and XI IPA 4 class as a control group
\end{abstract}


with 36 students. Taking technique of sample was a simple random sampling. The research data was gathered by learning outcome test of reaction rate subject matter for post-test which was analyzed by using Mann-Whitney test. The result of hypothesis with Mann-Whitney test was $\mathrm{Z}_{\text {calculated }}=5,36, \mathrm{Z}_{\text {table }}=1.64$ at $\alpha=0.05$. Therefore, $\mathrm{Z}_{\text {calculated }}>\mathrm{Z}_{\text {table, }}$, which the hypothesisi of this research was accepted so there is an effect positive of mind mapping at the end of discovery learning toward students' learning outcome in XI IPA class of SMA Negeri 3 Makassar on buffer solution subject matter.

Keywords: Mind mapping, discovery learning model, student's learning outcome

\section{PENDAHULUAN}

Kurikulum 2013 adalah kurikulum yang dibuat dengan tujuan memperbaiki proses pembelajaran. Salah satu harapan kurikulum 2013 adalah peserta didik bisa aktif dan produktif dalam proses pembelajaran. Peserta didik didorong untuk belajar sendiri, aktif menemukan konsepkonsep dan prinsip. Untuk itu diperlukan suatu upaya penerapan kurikulum 2013 yang dapat mencapai tujuan dari kurikulum tersebut.

Sesuai dengan pandangan kontruktivisme, yaitu dalam proses pembelajaran perlu adanya keaktifan bagi peserta didik, dimana peserta didik mencari arti apa yang mereka pelajari, dan mengembangkan ide - ide baru dengan kerangka berpikir yang telah dimilikinya. Berdasarkan paparan wakil menteri pendidikan dan kebudayaan Republik Indonesia bidang pendidikan (2014) menerangkan bahwa di kurikulum 2013 kemampuan peserta didik harus seimbang antara hard skill dan soft skill.

Proses pembelajaran adalah suatu interaksi yang terjadi antara peserta didik dengan guru melalui suatu model pembelajaran demi mempermudah mencapai tujuan

pembelajaran. Restiyani (2016) menemukan beberapa penelitian menunjukkan bahwa kimia menjadi salah satu mata pelajaran yang kurang disukai karena materinya. Pada pembelajaran kimia banyak dijumpai materi yang abstrak, seperti konsep atom, bilangan oksidasi, laju reaksi, persamaan reaksi dan lainnya. Sehingga suasana kelas cenderung pasif, sedikit sekali peserta didik yang bertanya pada guru meskipun materi yang diajarkan belum dapat dipahami. Dalam pembelajaran seperti ini peserta didik merasa seolah-olah dipaksa untuk belajar sehingga jiwanya tertekan. Keadaan demikian menimbulkan kejengkelan dan kebosanan.

Hasil observasi dan informasi dari salah satu guru kimia mengenai hasil belajar peserta didik mata pelajaran kimia kelas XI di SMA Negeri 3 Makassar diperoleh bahwa ketuntasan rata-rata peserta didik pada pembelajaran kimia telah dicapai, namun belum maksimal. Hal ini dikarenakan peserta didik lebih cenderung menerima apa saja yang disampaikan oleh guru. Peserta didik cenderung menghafal rumus yang ada 
Pengaruh Mind Mapping di Akhir Model Discovery Learning terhadap Hasil Belajar Peserta Didik

Kelas XI IPA SMAN 3 Makassar (Studi pada Materi Pokok Larutan Penyangga)

pada materi ajar sehingga peserta didik masih bingung dalam menyelesaikan setiap soal yang diberikan. Oleh karena itu, rata- rata hasil belajar peserta didik dapat dimaksimalkan dengan cara menarik perhatian peserta didik melalui penerapan model discovery learning.

Model discovery learning adalah gambaran proses pembelajaran yang terjadi dalam kelas dari awal hingga akhir dengan mengacu pada peserta didik mendapatkan pengetahuan dan konsepnya sendiri melalui beberapa kegiatan seperti mengamati, menggolongkan, menduga, mencari, mengolah dan mengambil kesimpulan.

Peserta didik kurang memaknai proses pembelajaran yang berlangsung. Salah satu penyebabnya yaitu tidak adanya variasi dalam mencatat materi yang dapat mempermudah peserta didik dalam memahami. Kesulitan tersebut dapat diatasi dengan cara yang mendukung peserta didik dalam menghubungkan satu materi dengan materi yang lain. Salah satu solusi yang akan digunakan adalah pembuatan mind map. Tiarawati (2016) mengatakan mind map akan memudahkan peserta didik dalam memahami materi sebab melibatkan kerja otak secara alami yaitu menghubungkan satu dan yang lain.

Peserta didik diharapkan menggunakan mind mapping agar mampu memetakan materi - materi yang telah dia pahami sehingga peserta didik bisa mengetahui hubungan materi yang satu dan yang lain dan dapat memaknai hasil dari proses pembelajaran yang berlangsung.
Dari latar belakang di atas, maka penulis tertarik untuk mengkaji sebuah penelitian yang berjudul "Pengaruh Mind Mapping di Akhir Model Discovery Learning terhadap Hasil Belajar Peserta Didik Kelas XI IPA SMAN 3 Makassar (Studi pada Materi Pokok Larutan Penyangga)".

\section{METODE PENELITIAN}

Penelitian ini merupakan penelitian eksperimen semu. Variabel bebasnya adalah mind mapping di akhir model discovery learning dan model discovery learning tanpa mind mapping sedangkan variabel terikat yaitu hasil belajar peserta didik kelas XI IPA SMAN 3 Makassar pada materi pokok larutan penyangga.

Instrumen yang digunakan dalam penelitian ini yaitu dengan menggunakan tes berupa tes objektif dalam bentuk essay sebanyak 6 nomor yang telah melalui proses validasi isi oleh pihak yang berkompeten dan validasi item melalui uji coba soal pada peserta didik XII IPA SMAN 3 Makassar.

Hasil tes belajar peserta didik diubah ke dalam bentuk nilai dengan rumus sebagai berikut:

$$
\text { Nilai }=\frac{\text { skor yang diperoleh peserta didik }}{\text { skor maksimum }} \times 100
$$

Tabel 1. Kriteria Ketuntasan Belajar

Peserta didik SMAN 3 Makassar

\begin{tabular}{cc}
\hline Nilai & Kategori \\
\hline$\geq 75$ & Tuntas \\
$<75$ & Tidak Tuntas \\
\hline
\end{tabular}

$\%$ ketuntasan $=\frac{\text { jumlah siswa yang tuntas }}{\text { jumlah seluruh siswa }} \times 100 \%$ 
Instrumen pada penelitian ini juga menggunakan rubrik penilaian mind mapping yang telah divalidasi. Mind mapping yang dibuat peserta didik akan dinilai lalu dihubungkan dengan hasi belajar peserta didik. Terdapat enam aspek yang dinilai dari mind mapping yang dibuat peserta didik yaitu penentuan topik utama, kata kunci, hubungan cabang utama dengan cabang lainnya, desain, estetika, dan kedalaman materi.

Adapun hipotesis dari penelitian ini yaitu "ada pengaruh positif mind mapping di akhir model disovery learning terhadap hasil belajar peserta didik kelas XI IPA SMAN 3 Makassar (Studi pada Materi Pokok Larutan Penyangga)

\section{HASIL DAN PEMBAHASAN}

\section{A. Hasil Penelitian}

\section{Analisis Statistik Deskriptif}

Tujuan analisis statistik deskriptif yaitu untuk memberikan gambaran umum mengenai karakteristik pencapaian hasil belajar peserta didik pada kelompok eksperimen dan kelompok kontrol.

Tabel 2. Nilai Statistik Hasil Belajar Peserta Didik

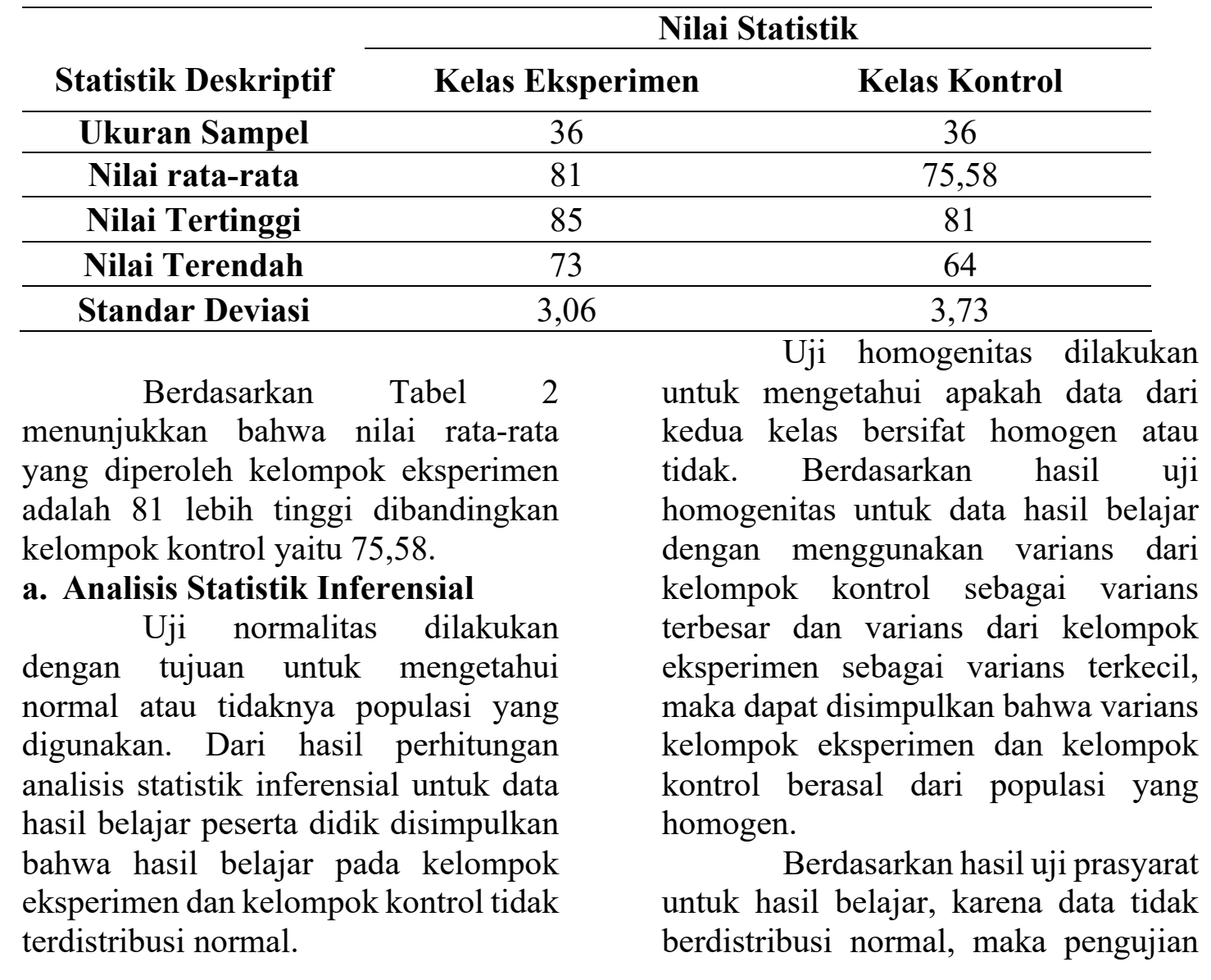

Nilai Statistik 
Pengaruh Mind Mapping di Akhir Model Discovery Learning terhadap Hasil Belajar Peserta Didik

Kelas XI IPA SMAN 3 Makassar (Studi pada Materi Pokok Larutan Penyangga)

hipotesis tidak dapat dilakukan menggunakan uji parametrik (uji-t), sehingga pengujian hipotesis dilakukan melalui uji statistik non-parametrik, yaitu uji Mann-Whitney.

Hasil analisis uji MannWhitney menunjukkan nilai $Z_{\text {hitung }}=$ 5,36 dan nilai $Z_{\text {tabel }}$ pada taraf kepercayaan 0,05 sebesar 1,64. Dari analisis uji hipotesis ini diperoleh $Z_{\text {hitung }}>Z_{\text {tabel }}$, maka $\mathrm{H}_{0}$ ditolak dan $\mathrm{H}_{1}$ diterima. Dengan demikian, dapat disimpulkan bahwa terdapat pengaruh positif mind mapping di akhir model discovery learning terhadap hasil belajar peserta didik kelas XI IPA SMAN 3 Makassar pada materi pokok larutan penyangga.

\section{B. Pembahasan}

Penelitian ini dilakukan untuk mengetahui pengaruh mind mapping di akhir model discovery learning terhadap hasil belajar peserta didik SMA Negeri 3 Makassar pada materi larutan penyangga. Sampel pada penelitian ini terdiri dari dua kelas, yaitu kelas XI IPA3 sebagai kelompok eksperimen dibelajarkan dengan pembuatan mind map di akhir model discovery learning dan kelas $\mathrm{XI}_{\mathrm{IPA}}$ sebagai kelompok kontrol yang hanya dibelajarkan menggunakan model discovery learning tanpa pembuatan mind map.

Analisis deskriptif pada hasil belajar peserta didik seperti yang ditunjukkan pada tabel 2 bahwa nilai rata-rata hasil belajar peserta didik pada kelompok eksperimen yaitu 81 sedangkan pada belajar kelompok kontrol yaitu 75,58. Hal ini dikarenakan pada kelompok eksperimen, peserta didik membuat mind mapping sehingga konsep dan pengetahuan yang ditemukan peserta didik dicatat dan diatur secara efektif dalam satu lembar kertas.

Perbedaan data yang diperoleh di kelompok eksperimen dan kelompok kontrol disebabkan karena pada kelompok eksperimen digunakan mind mapping yang dapat memudahkan peserta didik dalam menata konsep dan pengetahuan yang diperoleh, menetukan poin penting mengenai pokok materi yang dibahas selama membuat kesimpulan sehingga proses pembelajaran yang berlangsung dapat dimaknai oleh peserta didik. Mind mapping adalah suatu cara mencatat yang sangat efektif dengan hanya menggunakan kata kunci dan simbol yang membuat peserta didik mudah untuk mengingat konsep yang ditulis. Seperti yang dikemukakan oleh Naz (2013), diketahui bahwa penguasaan konsep peserta didik dapat ditingkatkan dengan penggunaan diagram maupun gambar secara sistematis seperti penggunaan mind mapping. Selain itu, peserta didik lebih aktif karena memiliki hak untuk mengungkapkan pendapat atau menjawab pertanyaan. Berbeda dengan proses pembelajaran di kelompok kontrol yang hanya menggunakan model discovery learning yang sebagian peserta didik aktif dalam mengemukakan pendapatnya untuk menjawab rumusan masalah yang telah dibuat oleh peserta didik. Seperti yang telah dilakukan oleh Sari (2016) mengatakan mind mapping sangat bermanfaat bagi peserta didik untuk memudahkan dalam mengingat, 
menghemat waktu, mengatur pikiran dan hobi, juga bisa menjadi media bermain, bersenang-sennag dalam menuangkan imajinasi yang tentunya memunculkan kreativitas.

Proses pembelajaran yang bermakna dimana peserta didik mampu mengkoneksikan informasi-informasi yang didapatnya sendiri selama proses pembelajaran, ini membuat informasi yang didapat akan tersimpan lebih lama di long term memory (Asyhuri, 2017).

Tabel 3. Persentase Hasil Penilaian Mind Mapping Peserta Didik Kelompok Eksperimen

\begin{tabular}{cccccccc}
\hline Aspek Yang Dinilai & $\begin{array}{c}\text { Penentuan } \\
\text { topik } \\
\text { utama }\end{array}$ & $\begin{array}{c}\text { Kata } \\
\text { Kunci }\end{array}$ & $\begin{array}{c}\text { Hubunga } \\
\text { n Cabang } \\
\text { Utama }\end{array}$ & $\begin{array}{c}\text { Desa } \\
\text { in }\end{array}$ & $\begin{array}{c}\text { Esteti } \\
\text { ka }\end{array}$ & $\begin{array}{c}\text { Kedalaman } \\
\text { Materi }\end{array}$ \\
\hline Pertemuan I & Sangat baik & 97,22 & 50 & - & 13,89 & 72,22 & 100 \\
\cline { 2 - 8 } & Baik & 2,78 & 47,22 & - & 27,78 & 27,78 & - \\
\cline { 2 - 8 } & Cukup & - & 2,78 & - & 55,56 & - & - \\
\hline Kurang Baik & - & - & 100 & 2,78 & - & - \\
\cline { 2 - 8 } & Sangat baik & - & 83,33 & - & 22,22 & 41,67 & - \\
\cline { 2 - 8 } & Baik & 80,56 & 16,67 & - & 55,56 & 47,22 & 100 \\
\cline { 2 - 8 } Pertemuan II & Kurang Baik & - & - & 100 & - & - & - \\
\cline { 2 - 8 } III & Sangat baik & - & 47,22 & - & 27,78 & 83,33 & 52,78 \\
\cline { 2 - 8 } & Baik & 88,89 & 52,78 & 44,44 & 61,11 & 27,78 & 47,22 \\
\cline { 2 - 8 } & Kukup & 11,11 & - & 55,56 & 11,11 & - & - \\
\hline
\end{tabular}

Hasil penelitian menunjukkan bahwa perpaduan antara discovery learning dengan mind mapping di akhir model discovery learning membuat hasil belajar lebih baik, dimana peserta didik mampu menghubungkan materi yang satu dengan yang lain melalui mind mapping.

Hasil pengujian hipotesis dengan menggunakan uji MannWhitney menunujukkan $H_{o}$ ditolak dan $H_{l}$ diterima yang berarti hipotesis yang diajukan di terima yakni ada pengaruh positif mind mapiing di akhir model discovery learning terhadap hasil belajar peserta didik kelas XI IPA
SMAN 3 Makassar pada materi pokok larutan penyangga. Kajian dari

Apriyanto (2014), mengatakan bahwa penggunaan mind mapping membantu peserta didik untuk mengorganisasikan pemikiran mereka. Hal ini sejalan dengan penelitian yang dilakukan Putri (2017), diketahui bahwa penguasaan konsep peserta didik mempengaruhi kemampuan peserta didik dalam memahami konten secara benar. Menurut Naz (2013), diketahui bahwa penguasaan konsep peserta didik dapat ditingkatkan dengan penggunaan diagram maupun gambar secara 
Pengaruh Mind Mapping di Akhir Model Discovery Learning terhadap Hasil Belajar Peserta Didik

Kelas XI IPA SMAN 3 Makassar (Studi pada Materi Pokok Larutan Penyangga)

sistematis seperti penggunaan mind maps (Asyhuri, 2017).

\section{KESIMPULAN DAN SARAN}

\section{A. Kesimpulan}

Hasil penelitian yang telah dilakukan dapat disimpulkan bahwa terdapat pengaruh mind mapping di akhir model discovery learning terhadap hasil belajar peserta didik kelas XI IPA SMA Negeri 3 Makassar pada materi pokok larutan penyangga.

\section{B. Saran}

$$
\text { Saran yang dapat }
$$

dikemukakan dari hasil penelitian ini adalah:

1. Kepada guru, khususnya guru kimia untuk menerapkan mind mapping di akhir model discovery learning guna meningkatkan hasil belajar siswa. Selain itu, membiasakan siswa dalam membuat mind map akan membantu cara berpikir siswa dalam menentukan poin penting dalam pembelajaran.

2. Kepada peneliti selanjutnya, diharapkan untuk memberi pengertian kepada sisswa untuk menyediakan alat tulis untuk membuat mind map yang benar terlebih dahulu.

\section{DAFTAR PUSTAKA}

Apriyanto, dody., Sri, M dan Elfi,S. 2014. Pengaruh Metode Pembelajaran Mind Mapping dan Kemampuan Memori Peserta didik Terhadap Prestasi Belajar Kimia Pada Pokok Bahasan Hukum-Hukum Dasar Kimia
Pada Peserta didik Kelas $\mathrm{X}$ Semester Gasal Di Sma Negeri 1 Mojolaban Tahun Pelajaran 2012/ 2013. Jurnal Pendidikan Kimia (JPK). Vol. 3 No. 3. ISSN 2337-9995

Naz, A., \& Nasreen, A. 2013. An Exploration of Students' Misconceptions about the Concept $^{\text {" }}$ Classification of Animals" at Secondary Level and Effectiveness of Inquiry Method for Conceptual Change. Journal of Faculty Educational Sciences, Vol: 46, No. 2.

Putri, L. O. L., Rahman, T., dan Priyandoko, D. 2017. Analyzing Concepts Mastery and Misconceptions About Evolution of Biology Major Students. Journal of Physics: Conf. Series, http://doi.org/10.1088/17426596/755/1/011001

Restiyani, Erika dan evi,C,B. 2016. Analisis Kesulitan Belajar Kimia Peserta didik di SMAN X Kota Tangerang Selatan. Jurnal Penelitian dan Pembelajaran IPA. Vol. 2, No. 1, ISSN 2477-2038

Sari, Eka Novita., Saiful R dan Nur Rahayu U. 2016. Pengaruh Model Pembelajaran Discovery Learning Dengan Mind Mapping Terhadap Hasil Belajar Siswa Pada Materi Sel Di SMA. Unnes Science Education Journal. ISSN 2252-6617.

Tiarawati., I Made, A., dan Dewi, M. 2016. Pengembangan Aplikasi Mind Map Materi Fisika SMA Berbasis Android. Jakarta : Universitas Jakarta. ISBN : 978602-61045-0-2 
Tirtawati, Ni Luh Ratna., Adnyana, P. B.,Widiyanti, Ni Luh P. M. 2014. Pengaruh Pembelajaran Kuantum (Quantum Learning) dan Peta Pikiran (Mind

Mapping)Terhadap Keterampilan Berpikir Kreatif dan Hasil Belajar Biologi Siswa SMA. e-Jurnal Program Pascasarjana Universitas Pendidikan Ganesha. Program Studi IPA. Volume 4 Tahun 2014.

Wakil Menteri Pendidikan Dan Kebudayaan R.I Bidang Pendidikan. 2014. Konsep dan Implementasi Kurikulum 2013.
Jakarta: Kementerian Pendidikan Dan Kebudayaan.

Yates, T. B., \& Marek, E. A. 2014. Teachers Teaching Misconceptions : A Study Of Factors Contributing To High School Biology Students Acquisition Of Biological Evolution-Related

Misconceptions. Evolution: Education and Outreach, Vol. 7, $1-18$. 